\title{
Chemical and biocatalytical methods of determination of stereomeric composition of 1,4-di[(diethoxylphosphoryl)hydroxymethyl]benzene
}

\author{
Barbara Malinowska,* Piotr Mlynarz, and Barbara Lejczak \\ Department of Bioorganic Chemistry, Faculty of Chemistry, Wrocław University \\ of Technology, Wybrzeże Wyspiańskiego 27, 50-370 Wrocław, Poland \\ E-mail: barbara.malinowska@pwr.wroc.pl
}

Dedicated to Prof. Pawel Kafarski on the occasion of his $63^{\text {rd }}$ birthday

\begin{abstract}
Reaction of terephtalaldehyde with diethyl phosphite catalyzed by potassium fluoride and alumina has been intensively studied in the literature because of its stereoselective course which, despite of using non-chiral substrates, results in a predominant formation of one diastereoisomer. However, the absolute configuration of the formed 1,4-di[(diethoxyphosphoryl)hydroxymethyl]benzene remains to be undefined so far, because of its high symmetry and thus the failure of the methods commonly used in stereochemistry. Application of stereoselective biocatalysis appeared to be a successful way to help to determine stereomeric composition of this compound, which was resolved as $R R / S S$ mixture.
\end{abstract}

Keywords: Hydroxyphosphonates, Candida cylindracea lipase, terephtalic aldehyde, quinine, cyclodextrins

\section{Introduction}

Hydroxyphosphonates constitute a class of organophosphorus compounds possessing a wide variety of interesting properties. For example, they exhibit antibacterial, antiviral (Cidofovir®) and anticancer ${ }^{1}$ activities and were also recognized as inhibitors of sphingomielinase ${ }^{2}, \operatorname{renin}^{3}$, HIV protease ${ }^{4}$ and protein tyrosine phosphatase. ${ }^{5}$

An interesting sub-group of these compounds are those, which bear two phosphonic acid moieties. These groups may be arranged as/in hydroxybisphosphonic moiety, which are known as good ion chelating agents and also exhibit anti-osteoporotic activity ${ }^{6}$ (drugs such as: Didronel ${ }^{\circledR}$, Aredia ${ }^{\circledR}$, Fosamax ${ }^{\circledR}$ 'Bondronat ${ }^{\circledR}$, and Zometa $\left.{ }^{\circledR}\right)$. A different arrangement of two $\alpha$-hydroxyphosphonate groups in the molecule allows to suppose, that its complexing activity 
may be broaden to more spacious supramolecular guest molecules such as amino acids, so this class of compounds is used as synthons to obtain macrocyclic chemoreceptors. ${ }^{7}$ 1,4Di[(diethoxyphosphoryl)hydroxymethyl]benzene was a subject of investigation in many publications during the past ten years including its potential application for the synthesis of various macrocyclic structures ${ }^{8}$, application in dentistry ${ }^{9}$ and exploitation of the inhibitory activity toward kinases, because of the presence of a chemically stable C-P bond.

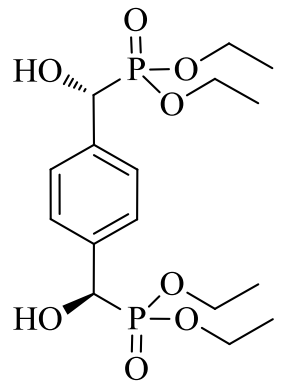

$\boldsymbol{R} \boldsymbol{R}$

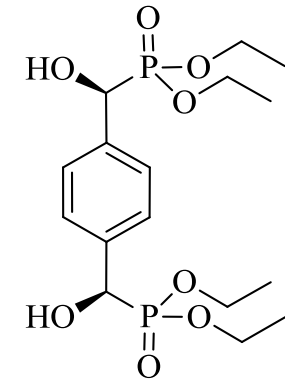

$R S, S R$

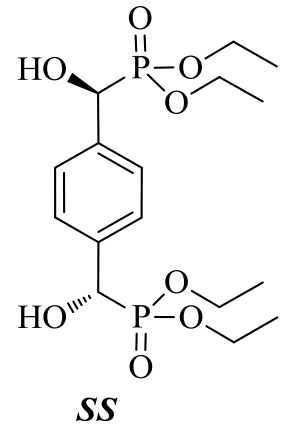

$S S$

Figure 1. Structures of stereoisomers of 1,4-di[(diethoxyphosphoryl)hydroxymethyl]benzene (1).

The structure of 1,4-di(phosphonohydroxymethyl)benzene (as well as its various analogues) was designed by 3D-QSAR, CoMFA (Comparative Molecular Field Analysis) and CoMSIA (Comparative Molecular Similarity Indices Analysis) methods as a potential inhibitor of 3phosphoglycerate kinase $(3-\mathrm{PGK})^{10}$ - one of the crucial enzymes of glycolysis. Enzymatic studies on its inhibitory action against on 3-PGK were conducted using stereoisomers of an unidentified stereochemistry. ${ }^{11}$ Thus, the definition of absolute configuration of 1,4di[(diethoxyphosphoryl)hydroxymethyl]benzene is indispensable for the proper determination of its inhibitory potency, as well as studies on the mode of its binding by the enzyme. 1,4$\operatorname{Di}[($ diethoxyphosphoryl)hydroxymethyl]benzene - the product of the reaction of terephthalaldehyde with diethyl phosphite - possesses two asymmetric carbon atoms and thus may exist in two diastereomeric forms (Figure 1). Their presence should be reflected in the NMR spectra. 


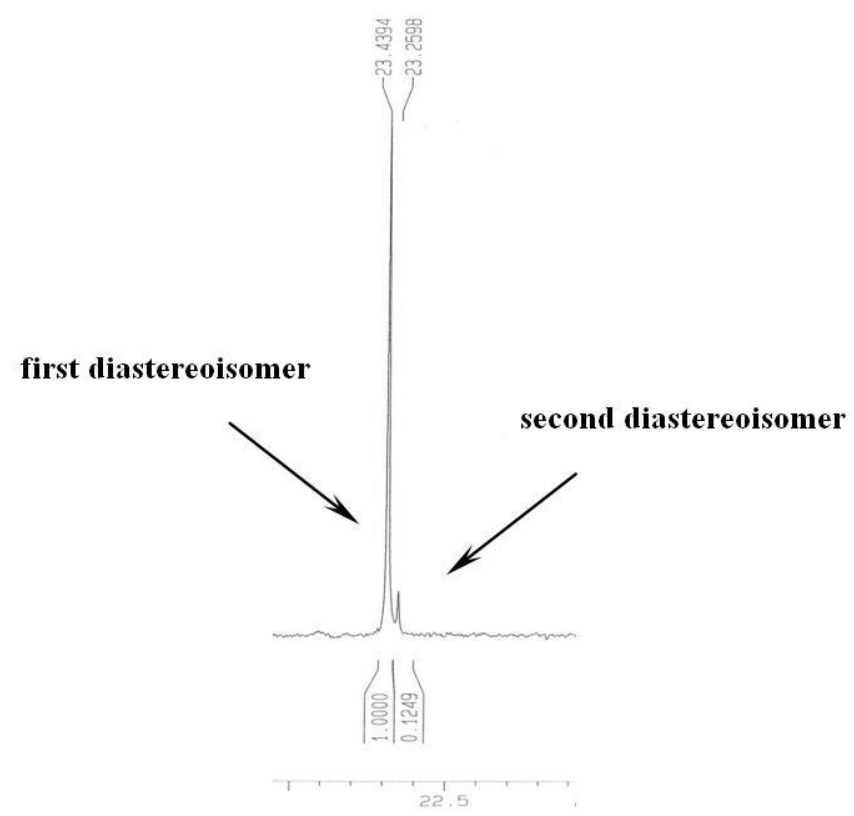

Figure 2. ${ }^{31} \mathrm{P}$ NMR spectrum of 1,4-di[(diethoxyphosphoryl)hydroxymethyl]benzene (1).

However, the strong domination of only one signal in ${ }^{31} \mathrm{P}$ NMR (Figure 2) and one doublet found in ${ }^{1} \mathrm{H}$ and ${ }^{13} \mathrm{C}$ NMR spectra for methylene group indicates, that most likely one diastereoisomeric form is predominantly present (about 90\%). This product may be either a mixture of $R R / S S$ enantiomers, or a symmetric $R S$-meso form. The preliminary stereochemical studies of this kind of compounds have been already carried out; however, a definitive clue was not reached. ${ }^{12}$

The stereospecific reaction of synthesis of these di-phosphonates despite of using non-chiral reagents, was earlier reported for the synthesis of a similar compound, namely tetraphenyl 1,4phenylenebis(aminomethylene)diphosphonate obtained by addition of diphenyl phosphite to Schiff bases ${ }^{13}$. The dependence of stereochemical composition of products on the structures of used terephthalic imines was investigated ${ }^{14}$ and a possible mechanism of a predominant formation of one diastereoisomer formation from achiral substrates was supposed. ${ }^{15}$ The formation of only one diastereoisomer, namely meso form of this compound was well documented $^{16}$ which strongly suggests that the similar stereochemical phenomenon may occur during the synthesis of 1,4-di[(diethoxyphosphoryl)hydroxymethyl]benzene.

The most versatile method for the absolute configuration determination is X-ray. However, we were unsuccessful in obtaining crystals of $\mathbf{1}$ and, therefore, NMR methods were employed to solve this problem.

In order to obtain stereomeric significant signal separation, various chiral solvating (CSA) and derivatizing (CDA) agents were tested. The results obtained by these techniques were carefully analyzed and compared to distinguish if spectroscopically achieved signals derive from the chiral centers present in one meso-molecule $(R / S)$ or originate from the mixture of enantiomers $(R R / S S)$. 


\section{Results and Discussion}

\section{${ }^{31}$ P NMR spectroscopy}

The isolation of the second stereoisomer (about 10\% of obtained hydroxyphosphonate) proved unsuccessful. Therefore, we decided to carry out NMR studies on the stereochemistry of only major isomer without its separation from the minor one. The first approach relied on the use of cyclodextrins, which are known chiral discriminators successfully used for various classes of phosphonates ${ }^{17}$ by forming an inclusion complexes with hydrophobic parts of these molecules.

In case of compound $\mathbf{1}$, the hydrophobic skeleton is blocked from both sides by relatively bulky and hydrophilic moieties, which protect the guest molecule against formation of inclusion complexes. Therefore, the variety of cyclodextrins differing in ring size and rim substitution were tested ( $\alpha$-, $\beta$-, $\gamma$-and - HP- $\gamma$ cyclodextrins) but only the $\gamma$-cyclodextrin and HP- $\gamma$ cyclodextrin possessing sufficiently wide interior cavity to complex compound $\mathbf{1}$ gave some results.

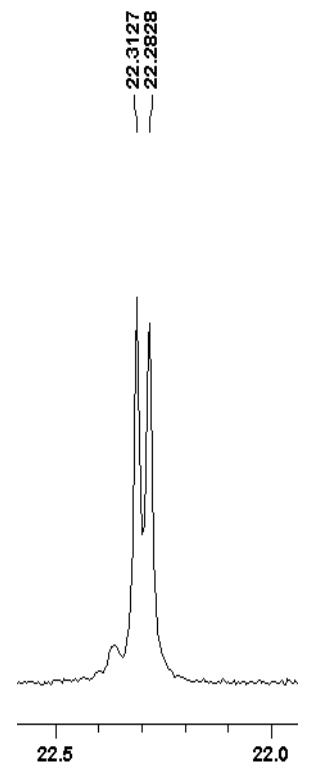

Figure 3. ${ }^{31} \mathrm{P}$ NMR spectrum of a complex of compound $\mathbf{1}$ with HP- $\gamma$-cyclodextrin.

The separation of signals was unsatisfactory and not applicable to reliably compare the response from both diastereoisomeric forms (Figure 3). Slight difference in chemical shifts between two main peaks $(\Delta \delta=0,03 \mathrm{ppm})$ may, however, suggest that these signals could originate from one molecule - namely meso-form. 


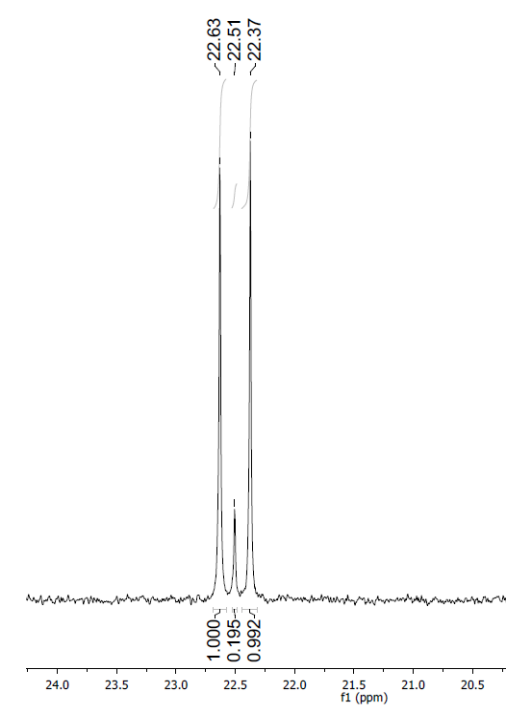

Figure 4. ${ }^{31} \mathrm{P}$ NMR spectrum of 1,4-di[(diethoxyphosphoryl)hydroxymethyl]benzene $\mathbf{1}$ in the presence of quinine.

In order to verify the obtained result, in the next step quinine - a commonly used chiral discriminator - was applied. This compound is able to interact non-covalently with - $\mathrm{OH}$ moieties of hydroxyphosphonates, ${ }^{18}$ which results in discrimination of phosphorous and proton signals from each stereoisomer.

The distribution of signals in the NMR spectra of $\mathbf{1}$ with quinine (Figure 4) suggests the presence of three stereoisomers with a significant predominance of the two of them. Major signals are present in an equimolar ratio.

Thus, the observed splitting of a major signal did not allow to determine if the product is a meso-form or a diastereomeric mixture. Therefore, ${ }^{31} \mathrm{P}$ NMR spectra of compound $\mathbf{1}$ in the presence of both, quinine and cyclodextrins, revealed usefulness of this technique in a differentiation of differing chiral centers. Next, we exploited a common chiral derivatizing reagent: $O$-methyl mandelic acid (MPA), which resulted in a formation of compounds $\mathbf{2} \mathbf{b}$ and $\mathbf{3 b}$ (Figure 5).<smiles>CCOP(=O)(OCC)C(OC(=O)[C@@H](OC)c1ccccc1)c1ccc(C(OC(=O)[C@H](OC)c2ccccc2)P(=O)(OCC)OCC)cc1</smiles>

2b<smiles>CCOP(=O)(OCC)C(O)c1ccc(C(OC(=O)[C@@H](OC)c2ccccc2)P(=O)(OCC)OCC)cc1</smiles>

3b

Figure 5. Structures of $\mathbf{1}$ mono- and diacylated by MPA. 
Also in this case, the ${ }^{31} \mathrm{P}$ NMR spectra of compounds $\mathbf{2} \mathbf{b}$ and $\mathbf{3 b}$ did not allow determinate of configuration of the obtained stereoisomers. The occurrence of long-range coupling between two non equivalent phosphorus atoms of $\mathbf{3 b}$ via seven bonds additionally complicates the assignment of its stereochemistry. This phenomenon is described in a separate paper ${ }^{19}$ and substantially complicates the stereochemistry assignment (Figure 6). ${ }^{31} \mathrm{P}$ NMR spectra of reaction products with both esterified hydroxyl groups (compound $\mathbf{2 b}$ ) also did not define the configuration of the substrate. Magnetically equal phosphorus atoms attached to a carbons of $R$ or $S$ configuration of $R R / S S$ enantiomers would yield two signals in ${ }^{31} \mathrm{P} \mathrm{NMR}$, which results from formation of $(S) R R(S)$ and $(S) S S(S)$ products. On the other hand, the symmetry of a meso form would be disorganized by a derivatization with $(S)$ - $O$-methyl mandelic acid, due to the formation of the compound with $(S) R S(S)$ configuration. Thus, this effort also failed.

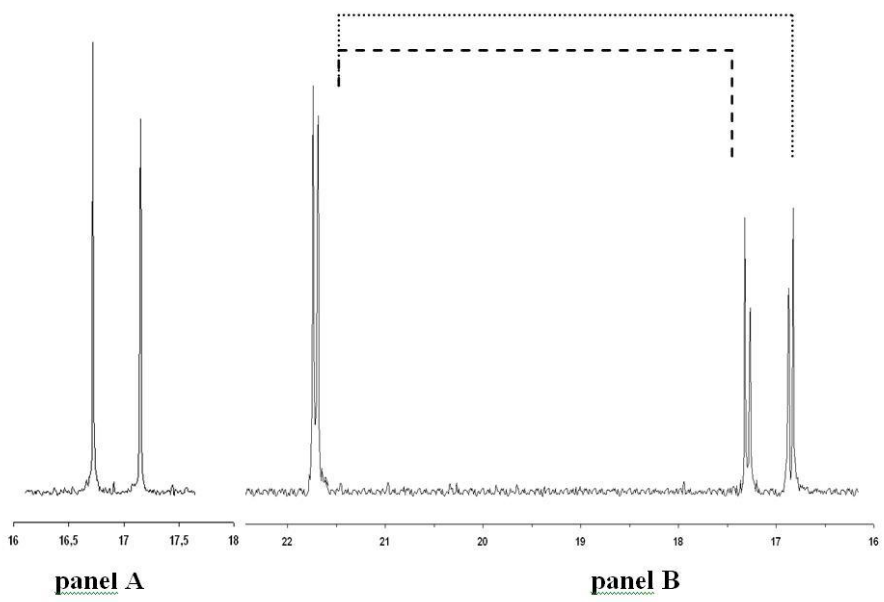

Figure 6. ${ }^{31} \mathrm{P}$ NMR spectra of $\mathbf{2 b}$ (panel A) and $\mathbf{3 b}$ (panel B). Due to similarity of chemical shifts and small amounts of the second diasteroisomeric substrate its presence is almost invisible in the spectra.

\section{Stereoselective biocatalysis}

Biocatalysis appeared to be a helpful method in a determination of the stereochemical composition of the investigated compound 1. In order to employ the most common biocatalysts lipases, compound $\mathbf{1}$ was acylated with butyryl chloride, giving diester $\mathbf{2 a}$ suitable for enzymatic hydrolysis. Because of the presence of two ester bonds, which potentially may be hydrolyzed by these enzymes, the formation of two products of a hydrolysis is possible. They are as following: totally hydrolyzed phosphonate $\mathbf{1}$ and a product of a hydrolysis of only one acyl group, $i$. $e$. compound 3a. As a result the reaction mixture was composed of three products: non-reacted substrate $\mathbf{2 a}$ and two products of enzymatic hydrolysis $\mathbf{1}$ and 3a. Determination of the structure of compound 2a allowed to assign the stereochemistry of a starting 1,4di[(diethoxyphosphoryl)hydroxymethyl]benzene. 
Assuming stereo preference of the used lipase there are only two possible ways of stereoselective biotransformation, depending on a different stereochemistry of a substrate. When the substrate is a mixture of $R R$ and $S S$ enantiomers, lipase should act according to a kinetic resolution mode (with $50 \%$ maximal yield). In the case of a meso form of a substrate, the enzyme should dissymmetrize $\mathbf{2 a}$ by conversion of one chiral center with $100 \%$ theoretical yield.<smiles></smiles>

Figure 7. Candida cylindracea lipase catalyzed reaction.

The optical activity of the major hydrolysis product - non-symmetric 3a equaled +28 (measured in methanol upon 55,4\% conversion of substrate) and confirmed the stereoselectivity of an enzymatic cleavage. Also its ${ }^{31} \mathrm{P}$ NMR spectrum measured in the presence of quinine, indicated the formation of two stereoisomers in a 1:5.8 molar ratio (Figure 8). 


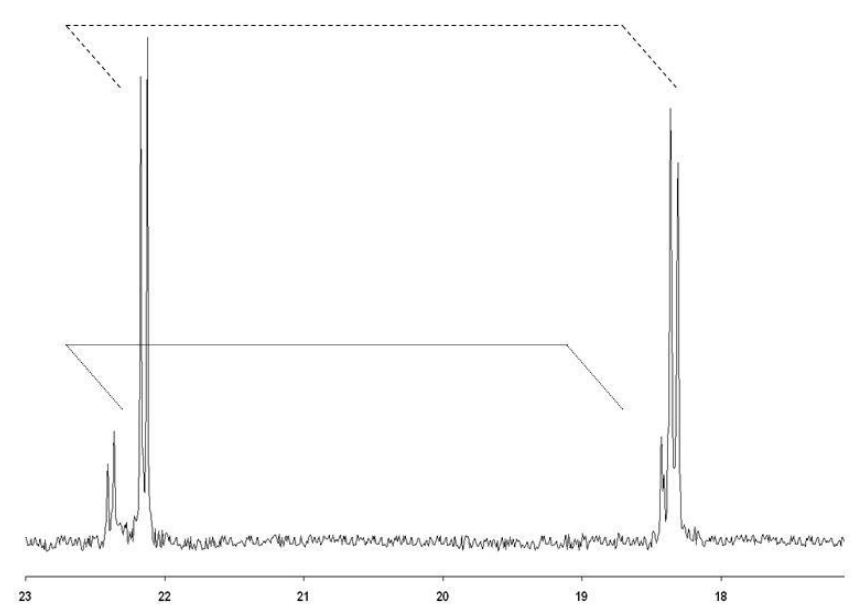

Figure 8. ${ }^{31} \mathrm{P}$ NMR spectrum of the product 3a obtained from a biocatalytic process, recorded with quinine as a chiral discriminator.

Despite the confirmation of the stereoselectivity of enzyme action, it still remains impossible to determine the absolute configuration of a product 3a. The determination of a configuration of the used substrate 2a (RR/SS versus meso) was possible only after consideration of optical activity of a totally hydrolyzed product $\mathbf{1}$ and unreacted substrate 2a. Thus, if the substrate was of a meso configuration - these two compounds would be achiral, whereas in the case of diastereomeric $R R / S S$ pair - both of these products should be non-racemic mixtures of enantiomers. Thus, the reaction was stopped after about $50 \%$ of conversion of compound $2 \mathbf{a}$ and its optical activity was determined. Since compound 2a is achiral, the observed optical rotation $\left(\alpha=-48^{0}\right)$ of the non-reacted substrate $\mathbf{2 a}$, excludes meso form as the substrate of enzymatic hydrolysis.

Compiled results of optical activities of both $\mathbf{2 a}$ and $\mathbf{3 a}$ clearly indicate that the substrate of the reaction was a mixture of $R R$ and $S S$ stereoisomers of 1,4$\operatorname{di}[($ diethoxyphosphoryl)hydroxymethyl]benzene 1 . Thus, the addition of diethyl phosphite to terephthalaldehyde affords predominantly equimolar mixture of these stereoisomers as the major product, with small amounts $(<13 \%)$ of a meso form as a minor one. 


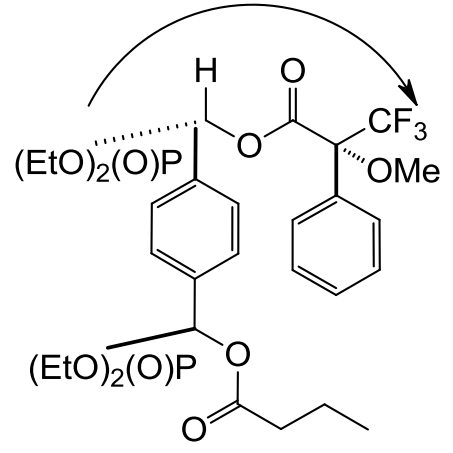

$4 a$

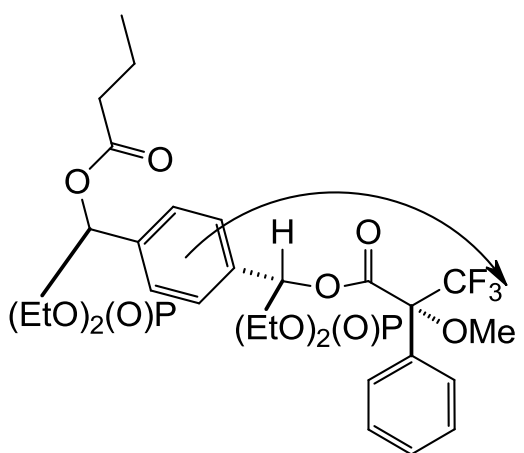

4b

Figure 9. The anisotropic effect of a phenyl ring and phosphonic moiety on chemical shifts of $O$ methyl group in $(R)$-MTPA esters of $\mathbf{3 a}: S S(R) \mathbf{4 a}$ and $R R(R) \mathbf{4 b}$.

In order to determine the absolute configuration of the product 3a the Mosher method was used. It relays on the analysis of the NMR spectra of the obtained products by acylation of this compound with $(S)-(+)$ - $\alpha$-methoxy- $\alpha$-trifluoro-methylphenylacetyl chloride.

The indicative parameters were the differences in chemical shifts originating from the interactions of the methoxy group of a Mosher reagent and phosphonate moieties (Figure 9). Thus, the chemical shift of a methoxy group from $S S$ enantiomer (4b) was expected downfield in ${ }^{1} \mathrm{H}$ NMR spectra. The opposite effect occurred if there was an interaction between phosphonate moiety and aromatic ring observed for $(R R)-\mathbf{3 a}$.

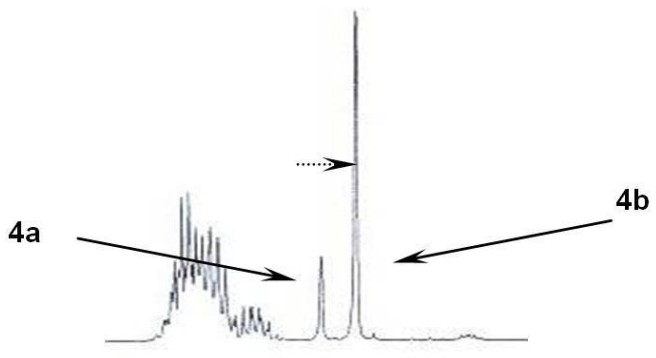

Figure 10. ${ }^{1} \mathrm{H}$ NMR spectrum of $O$-methyl region of compounds $4 \mathbf{a}$ and $\mathbf{4 b}$ with revealed shielding effects.

The ${ }^{1}$ HNMR signals originated from $O$-methyl moieties reveal the presence of nonequimolar mixture of both enantiomeric forms ( $71 \%$ ee - reaction is not fully stereospecific). The observed negative chemical shift of a predominant enantiomer of $(\mathbf{3 a})-(R)-\operatorname{MTPA}\left(\Delta \delta_{R R(R), S S(R)}=-\right.$ $0.117 \mathrm{ppm}$ ) indicates its $R R(R)$ stereochemistry (Figure 10). 
Table 1. Enantiomeric course of enzymatic reaction with Candida cylindracea lipase

\begin{tabular}{cccccc}
\hline Time & Conversion $\%$ & Ratio of products $\mathbf{2 a}: \mathbf{3 a}: \mathbf{1}$ & ee $\%$ of $\mathbf{2} \mathbf{a}^{\mathrm{a}}$ & ee $\%$ of $\mathbf{3 a} \mathbf{a}^{\mathrm{b}}$ & ee $\%$ of $\mathbf{1}^{\mathrm{b}}$ \\
\hline 1 day & 13,6 & $6.3: 1.0: 0.0$ & $6.1 \%(S S)$ & $10.6 \%(R R)$ & $90.2 \%(S S)$ \\
3 days & 40,6 & $2.1: 1.0: 0.4$ & $10.2 \%(S S)$ & $27.3 \%(R R)$ & $81.2 \%(S S)$ \\
5 days & 63,0 & $2.1: 1.0: 0.8$ & $19.9 \%(S S)$ & $54.3 \%(R R)$ & $78.3 \%(S S)$ \\
7 days & 83,8 & $0.4: 1.0: 1.0$ & $38.8 \%(S S)$ & $70.2 \%(R R)$ & $63.9 \%(S S)$ \\
\hline
\end{tabular}

All ee\% values were calculated from ${ }^{31} \mathrm{P}$ NMR spectra by integration of resulting peaks and calculating $R R /(R R+S S) * 100 \%$.

${ }^{a}$ The enantiomeric excess was calculated from ${ }^{31} \mathrm{P}$ NMR spectra recorded in the presence of $\alpha-$ cyclodextrin.

${ }^{\mathrm{b}}$ The enantiomeric excess was calculated from ${ }^{31} \mathrm{P}$ NMR spectra with quinine used as a chiral discriminator.

For a better analysis of the stereospecificity of Candida cylindracea lipase action, the reaction was stopped after 1, 3, 5 and 7 days. All reaction products were separated and their stereochemical composition was determined (see Table 1). The enantiomeric excess of the products was assigned by ${ }^{31} \mathrm{P}$ NMR measurements in the presence of chiral discriminators: the $\alpha$ cyclodextrin for $\mathbf{2 a}$ and quinine for 3a (see Figure 8) and for 1,4di[(diethoxyphosphoryl)hydroxy-methyl]benzene 1 (Figure 11, panel A).

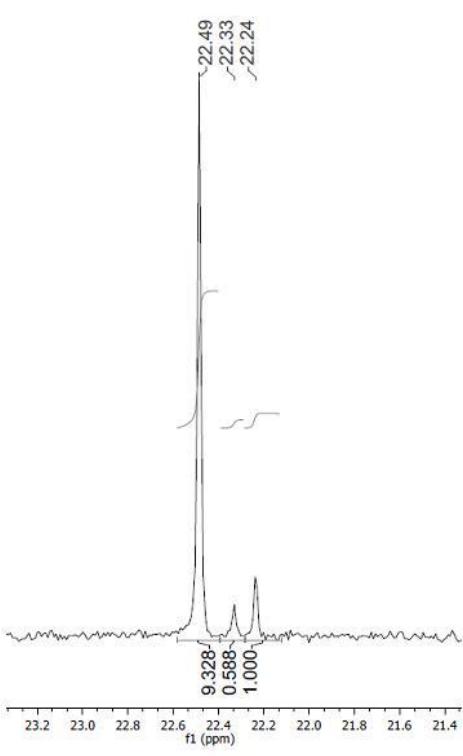

Panel A

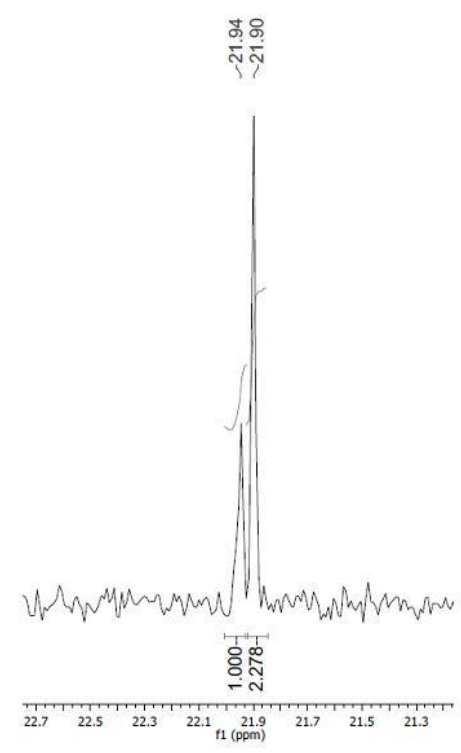

Panel B

Figure 11. ${ }^{31} \mathrm{P}$ NMR spectra of non-racemic $\mathbf{1}$ in the presence of quinine (panel A) and nonracemic $\mathbf{2 a}$ in the presence of $\alpha$-cyclodextrin (panel B). 
The molecule of diester 2a possesses two alkyl fragments in the structure, which are able to form a complex with two cyclodextrin molecules, resulting in two signals in ${ }^{31} \mathrm{P}$ NMR spectra (Figure 11, panel B), which corresponds to the amounts of $R R$ and $S S$ enantiomers. The stereochemistry of all products was assigned in a relation to 3a. Hydrolysis of its fraction enriched by biocatalysis in the compound of $(R R)$ configuration enabled to obtain standardsamples for correlation studies. The enatiomeric excess of $\mathbf{2 a}$ obtained by biocatalysis was low and did not exceed $40 \% \mathrm{ee}_{S S}$ ( $E$ values of about 2.4-1.5, calculated from equation $\mathrm{E}=\ln \left[(1-\mathrm{C})\left(1-\mathrm{ee}_{\mathrm{s}}\right)\right] / \ln \left[(1-\mathrm{C})\left(1+\mathrm{ee}_{\mathrm{s}}\right)\right)$. The best stereoselectivities for the formation of 3a were achieved after 7 days of biocatalysis, which gave $70 \% e_{R R}$. It was slightly lower than obtained, when reaction was carried out in a milligram scale. This relatively high enantiomeric ratio resulted from two simultaneous hydrolysis reactions: $\mathbf{2 a}$ to $\mathbf{3 a}$ and $\mathbf{3 a}$ to compound $\mathbf{1}$. It was assumed that second step of hydrolysis has the decisive influence on stereochemical purities of monoester 3a and diol 1, what was reflected in changes of ee values of both compounds as showed in Table 1. In fact the first step of reaction provided compound 3a in only slight enantiomeric excess, which increases during the reaction course. The ee values of arising diol $\mathbf{1}$ were higher at the beginning of the kinetic resolution of almost racemic mixture of 3a (the second reaction step) and gradually decreased together with the reaction progress.

\section{Conclusions}

Biocatalysis due to its stereoselectivity is an excellent method for enrichment of racemic mixtures in one of stereomeric forms of the product or/and unreacted substrate. When studying compounds with two chiral centers it could be used as a technique helping tentative determination of their absolute configurations being both competitive and supplementary to the standard chemical derivatization techniques used for this purpose. In the case described in this paper the compilation of all of these methods required. The NMR data obtained for all the compounds studied in this work may serve as references in measurements of analogous structures.

\section{Experimental Section}

General. NMR spectra were measured on a Bruker AvanceTM 600 at $600.58 \mathrm{MHz}$ for ${ }^{1} \mathrm{H}$; 243.12 MHz for ${ }^{31} \mathrm{P}$ and $151.02 \mathrm{MHz}$ for ${ }^{13} \mathrm{C}$ in $\mathrm{CDCl}_{3}$ or on a Bruker Avance DRX 300 instrument operating at $300.13 \mathrm{MHz}$ for $1 \mathrm{H}$ and $121.50 \mathrm{MHz}$ for ${ }^{31} \mathrm{P}$ in $\mathrm{CDCl}_{3}$. Chemical shifts $(\delta)$ are reported in parts per million and coupling constants $(\mathrm{J})$ are given in Hertz. ${ }^{1} \mathrm{H}$ NMR are referenced to internal TMS $(\delta=0.00),{ }^{13} \mathrm{C}$ NMR spectra to the center line of $\mathrm{CHCl}_{3}(\mathrm{~d}=77.23)$ and $85 \%$ phosphoric acid in $\mathrm{D}_{2} \mathrm{O}$ for ${ }^{31} \mathrm{P}$ NMR spectra was used as external reference. Optical rotation was measured in $\mathrm{CHCl}_{3}$ using polAAr-31 polarimeter $(578 \mathrm{~nm})$. All compounds were purified by a gradient column chromatography using Merck Silica Gel 60 (63-230 mesh) or by 
HPLC (Varian, Dynamax HPLC Column 25021.4 mm; MICROSORB 300-10 C18). All materials were purchased from commercial suppliers: Sigma, Aldrich, Fluka, POCh and used without further purification. Acetonitrile, dichloromethane and pyridine were dried by distillation according to standard procedures. The specific activity of lipase from Candida cylindracea (currently called Candida rugosa) was $\geq 2$ units/mg.

\section{Complexes with cyclodextrins}

Cyclodextrins were dissolved in $0,6 \mathrm{~mL} \mathrm{D}_{2} \mathrm{O}$ according to their solubility in water: $(50 \mathrm{mg}(\alpha-$ CD), $71 \mathrm{mg}$ HP- $\alpha-\mathrm{CD}, 6.5 \mathrm{mg} \beta-\mathrm{CD}$ and $78 \mathrm{mg} \gamma-\mathrm{CD})$ and 270mg (HP- $\gamma-\mathrm{CD})$. Compounds 1 and $2 \mathbf{a}$ were added to these solutions to obtain 10 molar excess of a host molecule.

1,4-Di[(diethoxyphosphoryl)hydroxymethyl]benzene (1) was synthesized according to the method described by Texier-Boullet. ${ }^{20}$ Thus, terephthalaldehyde $(4,00 \mathrm{~g}, 30 \mathrm{mmol})$ was mixed with equal mass of KF and alumina (9 g each). Diethyl phosphite (9,11 g, $66 \mathrm{mmol}, 8,50 \mathrm{~mL})$ was slowly added with stirring at room temperature observing exothermic reaction and solidification of the mixture. The reaction mixture was left at room temperature for additional 12 $\mathrm{h}$ and after this time it was suspended in chloroform $(2 \times 60 \mathrm{~mL})$. After filtration of catalyst the product was purified by precipitation from condensed chloroform solution by slow addition of hexane which afforded white microcrystalline residue. (43\% yield) ${ }^{1} \mathrm{H}$ NMR $(300.13 \mathrm{MHz}$, $\left.\mathrm{CDCl}_{3}\right): \delta \mathrm{H} 7.45(4 \mathrm{H}, \mathrm{s}, 4 \mathrm{ArH}) ; 4.98\left(2 \mathrm{H}, \mathrm{d}, J_{\mathrm{HP}}=10.61, \mathrm{CHP}\right), 3.86-4.12\left(8 \mathrm{H}, \mathrm{m}, 4 \mathrm{xCH}_{3} \underline{\mathrm{CH}}_{2}-\right.$ ), $1.22\left(12 \mathrm{H}, \mathrm{t}, J=6.95,4 \mathrm{x} \underline{\mathrm{CH}}_{3} \mathrm{CH}_{2^{-}}\right),{ }^{31} \mathrm{P} \mathrm{NMR}\left(121.5 \mathrm{MHz}, \mathrm{CDCl}_{3}\right): \delta \mathrm{P} 21.88(\mathrm{~s}) ;{ }^{13} \mathrm{C} \mathrm{NMR}$ $\left(125.8 \mathrm{MHz}, \mathrm{CDCl}_{3}\right): \delta \mathrm{C} 136,51(\mathrm{~s}, 4 \mathrm{ArH}), 127,07-126,87(\mathrm{~m}), 70.44\left(\mathrm{dd},{ }^{1} J_{\mathrm{CP}}=158.12\right.$, $\left.{ }^{6} J_{\mathrm{CP}}=1.03\right), 63.04-63.16\left(4 \mathrm{xd},{ }^{2} J_{\mathrm{PC}}=7.26\right), 16.39-16-28\left(2 \mathrm{xd},{ }^{3} J_{\mathrm{PC}}=2.78\right),(\mathrm{TOF} \mathrm{MS} \mathrm{ES}+): \mathrm{m} / z$ Calcd for $\mathrm{C}_{16} \mathrm{H}_{28} \mathrm{O}_{8} \mathrm{P}_{2} \mathrm{Na}[\mathrm{M}+\mathrm{Na}]$, 433.1157; Found 433.1163

Di-butyl ester of 1,4-di[(diethoxyphosphoryl)hydroxy methyl]benzene (2a). Compound 1 $(3,50 \mathrm{~g}, 8,5 \mathrm{mmol})$ was suspended in $20 \mathrm{~mL}$ of chloroform containing triethylamine $(2.16 \mathrm{~g}, 21$ mmol, $2.95 \mathrm{~mL})$. Then butyryl chloride $(2.27 \mathrm{~g}, 21 \mathrm{mmol}, 1.6 \mathrm{~mL})$ was added dropwise at $0^{\circ} \mathrm{C}$. The reaction mixture was stirred for $2 \mathrm{~h}$ at room temperature and then refluxed by additional 6 hours. Product 2a was purified by means of silica liquid chromatography using ethyl acetate:2propanol $(9: 1 \mathrm{v} / \mathrm{v})$ as eluent ; $(\mathrm{Rf}=0.7)$. (93\% yield) ${ }^{1} \mathrm{H} \mathrm{NMR}\left(300.13 \mathrm{MHz}, \mathrm{CDCl}_{3}\right)$ : $\delta \mathrm{H} 7.46(\mathrm{~s}$, $\left.4 \mathrm{H}_{\mathrm{Ar}}\right), 6.13\left(\mathrm{~d}, 1 \mathrm{H}, \mathrm{C} \underline{\mathrm{HP}},{ }^{2} \mathrm{~J}_{\mathrm{HP}}=12.85\right), 4.08-3.91\left(\mathrm{~m}, 8 \mathrm{H}, \mathrm{CH}_{2}\right), 2.39\left(\mathrm{t}, 4 \mathrm{H}, \mathrm{OCO}-\mathrm{CH}_{2^{-}}\right.$ $\left.{ }^{3} J_{\mathrm{HH}}=7.43\right), 1.70-1.62\left(\mathrm{~m}, 4 \mathrm{H}, \mathrm{CH}_{2}-\underline{\mathrm{CH}}_{2}-\mathrm{CH}_{3}\right), 1.25-1.17\left(\mathrm{~m}, 12 \mathrm{H},-\mathrm{CH}_{3}\right), 0.92\left(\mathrm{t}, 6 \mathrm{H}, \mathrm{CH}_{2}-\mathrm{CH}_{2} 2^{-}\right.$ $\left.\mathrm{CH}_{3},{ }^{3} J_{\mathrm{HH}}=7.40\right),{ }^{31} \mathrm{P}$ NMR $\left(121.5 \mathrm{MHz}, \mathrm{CDCl}_{3}\right): \delta \mathrm{P} 18.21(\mathrm{~s}) ;{ }^{13} \mathrm{C} \mathrm{NMR}\left(125.8 \mathrm{MHz}, \mathrm{CDCl}_{3}\right)$ : $\delta \mathrm{C} 171.94, \mathrm{~s}, \mathrm{COO}, 134.14, \underline{\mathrm{C}}_{\mathrm{Ar}} \mathrm{CP}, 127.79, \mathrm{t}, \mathrm{C}_{\mathrm{Ar}}-\mathrm{H},{ }^{2} J_{\mathrm{PC}}=6.60,70.96, \mathrm{C}-\mathrm{P},{ }^{2} J_{\mathrm{PC}}=170.01,63.25$, d, O- $\underline{C H}_{2}-\mathrm{CH}_{3},{ }^{2} \mathrm{~J}_{\mathrm{PC}}=3.17,36.05, \mathrm{~s}, \underline{\mathrm{CH}}_{2}-\mathrm{CH}_{2}-\mathrm{CH}_{3}, 18.41$, s, O- $\mathrm{CH}_{2}-\underline{C H}_{3}, 16.35, \mathrm{~s}, \mathrm{CH}_{2}-\underline{C H}_{2}-$ $\mathrm{CH}_{3}, 13.65, \mathrm{~s}, \mathrm{CH}_{2}-\mathrm{CH}_{2}-\underline{\mathrm{CH}}_{3}$, (TOF MS ES+): $\mathrm{m} / z$ Calcd for $\mathrm{C}_{24} \mathrm{H}_{40} \mathrm{O}_{10} \mathrm{P}_{2} \mathrm{Na}[\mathrm{M}+\mathrm{Na}], 573.1995$; Found 573.1985

Di- $O$-Methyl mandelate ester of 1,4-di[(diethoxy phosphoryl)hydroxymethyl]benzene (2b, 3b) was obtained according to a modified general procedure of Kozlowski. ${ }^{21}$ Thus oxalyl chloride $(1.8 \mathrm{mmol}, 0.16 \mathrm{~mL})$ was added at $0^{\circ} \mathrm{C}$ to the reaction medium containing anhydrous acetonitrile $(5,4 \mathrm{~mL})$ and DMF $(1.8 \mathrm{mmol}, 0.19 \mathrm{~mL})$ placed in flask sealed with a rubber septum. 
The formation of white precipitate was observed, which dissolved after injection of $O$ - $(S)$ mandelic acid $(0,30 \mathrm{~g}, 1.8 \mathrm{mmol})$ in $2 \mathrm{~mL}$ of acetonitrile. Then the reaction mixture was left for 24 hours at room temperature. After this time volatile components of the reaction mixture were evaporated and the product was redissolved in dry acetonitrile and evaporated to dryness. This procedure was repeated two times to remove remains of unreacted oxalyl chloride. Obtained mandelic chloride was suspended in $2 \mathrm{~mL}$ of dry chloroform and compound 1 (0.295 g, 0.72 mmol) dissolved in mixture of dry pyridine $(0,3 \mathrm{~mL})$ and dry chloroform $(5 \mathrm{~mL})$ was added. The reaction mixture was left at room temperature for 48 hours with stirring and then evaporated. Obtained oil consisted of the mixture of diasteroisomers of compounds $\mathbf{2} \mathbf{b}$ and $\mathbf{3 b}$, which were separated and purified by means of silica liquid chromatography using ethyl acetate and propanol $(9: 1 \mathrm{v} / \mathrm{v})$ as eluent; ((2b) $\mathrm{Rf}=0.5,(\mathbf{3 b}) \mathrm{Rf}=0.25)$

Compound $\mathbf{3 b}$ was obtained as an equimolar mixture of diasteroisomers: $R R(S)$ and $S S(S){ }^{1} \mathrm{H}$

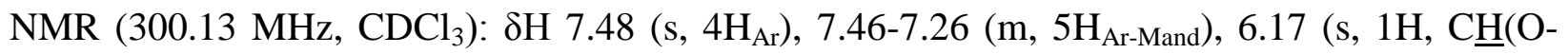
Mand)P, first diasteroisomer), 6.13 (s, 1H, $\mathrm{CH}(\mathrm{O}-\mathrm{Mand}) \mathrm{P}$, second diasteroisomer), 4.90 (d, 1H, $\left.\mathrm{CH}(\mathrm{OH}) \mathrm{P},{ }^{2} J_{\mathrm{HP}}=14.64\right), 4.11-4.01\left(\mathrm{~m}, 8 \mathrm{H}, \mathrm{CH}_{2}\right), 3.42$ (s, 3H, O-CH 3 (Mand) one disteroisomer), $3.40\left(\mathrm{~s}, 3 \mathrm{H}, \mathrm{O}-\mathrm{CH}_{3}\right.$ (Mand) second disteroisomer), 1.28-1.03 (m, 12H, $\left.-\mathrm{CH}_{3}\right),{ }^{31} \mathrm{P}$ NMR (121.5 $\left.\mathrm{MHz}, \mathrm{CDCl}_{3}\right): \delta \mathrm{P} 21.72, \mathrm{~d}, 16.84, \mathrm{~d}\left({ }^{7} J_{\mathrm{PP}}=5.64-6.51\right)$.

Compound $\mathbf{2 b}$ was obtained as an equimolar mixture of diasteroisomers: $(S) R R(S),(S) S S(S)$ ${ }^{1} \mathrm{H}$ NMR (300.13 MHz, $\left.\mathrm{CDCl}_{3}\right): \delta \mathrm{H} 7.49\left(\mathrm{~s}, 4 \mathrm{H}_{\mathrm{Ar}}\right), 7.51-7.27\left(\mathrm{~m}, 5 \mathrm{H}_{\mathrm{Ar}-\mathrm{Mand}}\right), 6.15$ (s , 1H, $\mathrm{C} \underline{\mathrm{H}}(\mathrm{O}-\mathrm{Mand}) \mathrm{P}$, first diasteroisomer), 6.11 (s, 1H, $\underline{\mathrm{CH}}(\mathrm{O}-\mathrm{Mand}) \mathrm{P}$, second diasteroisomer), 3.91$3.56\left(\mathrm{~m}, 8 \mathrm{H}, \mathrm{CH}_{2}\right), 3.43$ (s, 3H, O- $\mathrm{CH}_{3}$ (Mand) one disteroisomer), 3.40 (s, 3H, O- $\mathrm{CH}_{3}(\mathrm{Mand})$ second disteroisomer), 1.26-0.99 (m, 12H, $\left.-\mathrm{CH}_{3}\right),{ }^{31} \mathrm{P} \mathrm{NMR}\left(121.5 \mathrm{MHz}, \mathrm{CDCl}_{3}\right)$ : $\delta \mathrm{P} 17.15$, 16.84 .

\section{Enzymatic hydrolysis}

Compound $2 \mathbf{a}(0,110 \mathrm{mmol})$ was suspended in a biphasic system of $50 \mathrm{mM}$ phosphate buffer $(3,0$ $\mathrm{mL})$ and hexane $(0,8 \mathrm{~mL})$. Then $300 \mathrm{mg}$ Candida cylindracea lipase (specific activity $\geq 2$ units/mg) was added and the mixture was shaken for 48 hours at room temperature. Then biocatalyst was removed by filtration and products were extracted from reaction media by chloroform ( 2 x $50 \mathrm{~mL}$ ). Organic layer was dried over anhydrous magnesium sulfate. After filtration of a drying agent, the organic solvent was removed by evaporation. Products were separated and purified by means of HPLC (C-18 column; gradient: from $30 \%$ to $100 \%$ of acetonitrile in water; retention times: $10 \mathrm{~min}(\mathbf{1}), 13 \mathrm{~min}(\mathbf{3 a}), 18 \mathrm{~min}(\mathbf{2 a}))$.

Spectral data for compounds $\mathbf{1}$ and $\mathbf{2 a}$ are as described above. Compound 3a: ${ }^{1} \mathrm{H}$ NMR (300.13 $\left.\mathrm{MHz}, \mathrm{CDCl}_{3}\right): \delta \mathrm{H} 7.46, \mathrm{~s}-\mathrm{b}, 4 \mathrm{H}_{\mathrm{Ar}}, 6.15, \mathrm{~d}, 1 \mathrm{H}, \mathrm{C} \underline{\mathrm{H}}(\mathrm{O}-\mathrm{But}) \mathrm{P},{ }^{2} J_{\mathrm{HP}}=13.35,4.96, \mathrm{~d}, 1 \mathrm{H}, \mathrm{CHP}$, ${ }^{2} J_{\mathrm{HP}}=11.16,4.06-3.89, \mathrm{~m}, 8 \mathrm{H}, \mathrm{CH}_{2}, 2.40, \mathrm{t}, 2 \mathrm{H}, \mathrm{OCO}-\mathrm{CH}_{2^{-}}{ }^{3} J_{\mathrm{HH}}=7.32,1.72-1.59, \mathrm{~m}, 2 \mathrm{H}, \mathrm{CH}_{2^{-}}$ $\mathrm{CH}_{2}-\mathrm{CH}_{3}, 1.23-1.16, \mathrm{~m}, 12 \mathrm{H},-\mathrm{CH}_{3}, 0.92, \mathrm{t}, 3 \mathrm{H}, \mathrm{CH}_{2}-\mathrm{CH}_{2}-\mathrm{CH}_{3},{ }^{3} \mathrm{~J}_{\mathrm{HH}}=7.50,{ }^{31} \mathrm{P}$ NMR (121.5 $\left.\mathrm{MHz} \mathrm{CDCl}_{3}\right): \delta \mathrm{P} 21.65,18.24, \mathrm{~d},{ }^{7} J_{\mathrm{PP}}=6.02-6.13,{ }^{13} \mathrm{C} \mathrm{NMR}\left(125.8 \mathrm{MHz}, \mathrm{CDCl}_{3}\right): \delta \mathrm{C} 171.89$, $\mathrm{d}, \mathrm{COO}, 136.79,133.56, \mathrm{~m}, \mathrm{C}_{\mathrm{Ar}}-\mathrm{H}, 127.79, \mathrm{dd}, \underline{\mathrm{C}}_{\mathrm{Ar}}-\mathrm{CP},{ }^{2} J_{\mathrm{PC}}=5.89,{ }^{5} J_{\mathrm{PC}}=2.08,127.08, \mathrm{dd}, \underline{\mathrm{C}}_{\mathrm{Ar}}-\mathrm{CP}$, ${ }^{2} J_{\mathrm{PC}}=5.19,{ }^{5} J_{\mathrm{PC}}=2.07,70.54, \mathrm{C}-\mathrm{P},{ }^{2} J_{\mathrm{PC}}=158.81,69.84, \mathrm{C}-\mathrm{P},{ }^{2} J_{\mathrm{PC}}=169.54,63.25, \mathrm{~m}, \mathrm{O}-\underline{C H}_{2}-\mathrm{CH}_{3}$, 
36.02, s, $\underline{\mathrm{CH}}_{2}-\mathrm{CH}_{2}-\mathrm{CH}_{3}, 18.41, \mathrm{~s}, \mathrm{CH}_{2}-\underline{\mathrm{CH}}_{2}-\mathrm{CH}_{3}, 16.36, \mathrm{~m}, \mathrm{O}-\mathrm{CH}_{2}-\underline{\mathrm{CH}}_{3}, 13.55, \mathrm{~s}, \mathrm{CH}_{2}-\mathrm{CH}_{2}-\underline{\mathrm{CH}}_{3}$, (TOF MS ES+): $m / z$ Calcd for $\mathrm{C}_{20} \mathrm{H}_{34} \mathrm{O}_{9} \mathrm{P}_{2} \mathrm{Na}$ [M+Na], 503.1756; Found 503.1590

Mosher esters of 1,4-di[(diethoxyphosphoryl) hydroxy-methyl]benzene (4a, 4b) were prepared according to Dale and Mosher method. ${ }^{22}$ Thus, compound 3a (17 mg, 0,035 mmol) was dissolved in the mixture of dry dichlorometane $(1 \mathrm{~mL})$ and dry pyridine $(0,180 \mathrm{~mL})$ followed by addition of $(\mathrm{S})-(+)$ MTPA-Cl $(0,08 \mathrm{mmol}, 20 \mathrm{mg}, 15 \mu \mathrm{l})$ The mixture was left for 3 days at room temperature with slowly shaking. Then the excess of of 3-dimethylamino-1-propylamine $(0,20$ mmol, $20 \mathrm{mg}, 20 \mu \mathrm{l}$ ) was added and after 10 minutes reaction mixture was diluted with ethyl eter $(15 \mathrm{~mL})$ and washed once with cold diluted $\mathrm{HCl}$ and then water. Organic layer was dried over anhydrous magnesium sulfate and evaporated. Product was purified by means of HPLC (C-18 column; gradient: from $40 \%$ to $95 \%$ of acetonitrile in water; retention time: $28 \mathrm{~min}$ ) and analyzed with ${ }^{31} \mathrm{P}$ and ${ }^{1} \mathrm{H}$ NMR.

A mixture of diastereoisomers in $6: 1$ ratio was obtained. Isomer $R R(R){ }^{1} \mathrm{H}$ NMR $(300.13$ $\mathrm{MHz}, \mathrm{CDCl}_{3}$ ): $\delta \mathrm{H} 8.48\left(\mathrm{~s}, 4 \mathrm{H}_{\mathrm{Ar}}\right.$ ), 8.36 (s, $\left.5 \mathrm{H}_{\mathrm{Ar}-\mathrm{Mosh}}\right), 7.30$ (d, 1H, C$\left.(\mathrm{O}-\mathrm{Mosh}) \mathrm{P},{ }^{2} J_{\mathrm{HP}}=13.19\right)$, $7.18\left(\mathrm{~d}, 1 \mathrm{H}, \mathrm{C} \underline{\mathrm{H}}(\mathrm{O}-\mathrm{But}) \mathrm{P},{ }^{2} J_{\mathrm{HP}}=13.97\right), 5.05-4.94\left(\mathrm{~m}, 8 \mathrm{H}, \mathrm{CH}_{2}\right), 4.48\left(\mathrm{~s}, 3 \mathrm{H}, \mathrm{O}-\mathrm{CH}_{3}\right), 3.40$ (t, $\left.2 \mathrm{H}, \mathrm{OCO}-\mathrm{CH}_{2-}{ }^{3} J_{\mathrm{HH}}=6.96\right), 2.72-2.65\left(\mathrm{~m}, 2 \mathrm{H}, \mathrm{CH}_{2}-\mathrm{CH}_{2}-\mathrm{CH}_{3}\right), 2.27-2.11\left(\mathrm{~m}, 12 \mathrm{H},-\mathrm{CH}_{3}\right), 1.92$ $\left(\mathrm{t}, 3 \mathrm{H}, \mathrm{CH}_{2}-\mathrm{CH}_{2}-\mathrm{CH}_{3},{ }^{3} J_{\mathrm{HH}}=7.40\right),{ }^{31} \mathrm{P} \mathrm{NMR}\left(121.5 \mathrm{MHz}, \mathrm{CDCl}_{3}\right): \delta \mathrm{P} 18.07, \mathrm{~d}, 15.95, \mathrm{~d}\left({ }^{7} J_{\mathrm{PP}}=\right.$ 4.39-5.39).

Isomer $S S(R) \delta_{\mathrm{H}}\left(\mathrm{CDCl}_{3}\right)$ 8.48(s, $\left.4 \mathrm{H}_{\mathrm{Ar}}\right), 8.36\left(\mathrm{~s}, 5 \mathrm{H}_{\mathrm{Ar}-\mathrm{Mosh}}\right), 7.30(\mathrm{~d}, 1 \mathrm{H}, \mathrm{C} \underline{\mathrm{H}}(\mathrm{O}-\mathrm{Mosh}) \mathrm{P}$, $\left.{ }^{2} J_{\mathrm{HP}}=13.19\right), 7.18\left(\mathrm{~d}, 1 \mathrm{H}, \mathrm{CH}(\mathrm{O}-\mathrm{But}) \mathrm{P},{ }^{2} J_{\mathrm{HP}}=13.97\right), 5.05-4.94\left(\mathrm{~m}, 8 \mathrm{H}, \mathrm{CH}_{2}\right), 4.59$ (s, 3H, O$\left.\mathrm{CH}_{3}\right), 3.40\left(\mathrm{t}, 2 \mathrm{H}, \mathrm{OCO}-\mathrm{CH}_{2}{ }^{3} \mathrm{~J}_{\mathrm{HH}}=6.96\right), 2.72-2.65\left(\mathrm{~m}, 2 \mathrm{H}, \mathrm{CH}_{2}-\mathrm{CH}_{2}-\mathrm{CH}_{3}\right), 2.27-2.11(\mathrm{~m}, 12 \mathrm{H}$, $\left.-\mathrm{CH}_{3}\right), 1.92\left(\mathrm{t}, 3 \mathrm{H}, \mathrm{CH}_{2}-\mathrm{CH}_{2}-\mathrm{CH}_{3},{ }^{3} J_{\mathrm{HH}}=7.40\right),{ }^{31} \mathrm{P}$ NMR $\left(121.5 \mathrm{MHz}, \mathrm{CDCl}_{3}\right): \delta \mathrm{P} 18.07, \mathrm{~d}, 16.25$, $\mathrm{d}\left({ }^{7} J_{\mathrm{PP}}=4.39-5.39\right)$.

\section{Acknowledgements}

This work was financed from Project "Biotransformations for pharmaceutical and cosmetics industry" No.POIG.01.03.01-00-158/09-05 part-financed by the European Union within the European Regional Development Fund for the Innovative Economy".

\section{References}

1. Snoeck, R.; Holy A.; Dewolf-Peeters, C.; Van Den Oord, J.; De Clercq, E.; Andrei A. Antimicrob. Agents Chemother. 2002, 46, 3356.

2. Yokomatsu, T.; Murano, T.; Akiyama, T.; Koizumi, J.; Shibuya, S.; Tsuji, Y.; Soeda, S.; Shimeno, H. Bioorg.Med. Chem. Lett. 2003, 13, 229.

3. Patel, D. V.; Rielly-Gauvin, K.; Ryono, D. E.; Free, C. A.; Rogers, W. L.; Smith, S. A.; DeForrest, J. M.; Oehl, E. W.; Petrillo, E. W. Jr. J. Med. Chem. 1995, 38, 4557. 
4. Stowasser, B.; Budt, K.-H.; Jian-Qi, L.; Peyman, A.; Ruppert, D. Tetrahedron Lett. 1992, 33, 6625.

5. Hikishima, S.; Hashimoto, M.; Magnowska, L.;Bzowska, A.; Yokomatsu, T. Bioorganic \& Medicinal Chemistry Letters 2007, 17, 4173.

6. Sparidans, R.W.; Twiss; I. M.; Talbot, S. Pharm World Sci 1998, 5, 206.

7. Consiglio, G. A.; Failla, S.; Finocciaro, P. Molecules 2008, 13, 678.

8. Młynarz, P.; Rudzińska, E.; Berlicki, Ł.; Kafarski, P., Curr. Org. Chem. 2007, 11, 1593.

9. Moszner, N.; Zeuner, F.; Fischer, U.K.; Rheinberger, V. Macromolecular Chemistry and Physics 1999, 200, 1062.

10. Kotsikorou, E.; Sahota, G.; Oldfield, E. J. Med. Chem. 2006, 49, 6692.

11. (a) Caplan, N. A.; Pogson, C. I.; Hayes, D. J.; Blackburn, G. M. Bioorganic \& Medicinal Chemistry Letters 1998, 8, 515. (b) Caplan, N. A.; Pogson, C. I.; Hayes, D. J.; Blackburn, G. M. J. Chem. Soc., Perkin Trans. 1 2000, 1, 421.

12. (a) Gancarz, R. Scientific Papers of the Institute of Organic Chemistry, Biochemistry and Biotechnology of the Wrocław University No. 39; OficynaWydawnicza Politechniki Wrocławskiej, Wrocław, 1997. (b) Młynarz, P., Olbert-Majkut A., Śliwińska S., Schroeder G., Bańkowski, B., Kafarski, P., J. Mol. Struct. 2008, 873, 173.

13. (a) S. Failla, G. Consiglio, P. Finocchiaro, Phosphorus, Sulfur, and Silicon and the Related Elements 2011, 186, 983. (b) Lewkowski, J., Rybarczyk, M. Heteroatom Chem 2008, 19, 283. (c) Lewkowski, J. Phosphorus Sulfur Silicon 2005, 180,179.

14. (a) Nazarski, R.; Lewkowski, J.; Skowroński, R. Heteroatom Chemistry 2002, 13, 120.(b)

15. Lewkowski, J.; Stronka-Lewkowska, E. Phosphorus Sulfur Silicon 2006, 181, 1323

15. Lewkowski, J.; Rzeźniczak, M.; Skowroński, R. Heteroatom Chemistry 2000, 11, 144.

16. (a) Failla, S.; Finocchiaro, P. Phosphorus Sulfur Silicon 1995, 107, 79. (b) Młynarz P., Olbert-Majkut A., Śliwińska S., Schroeder G., Bańkowski B., Kafarski P. J. Mol. Struct. 2008, 873, 173.

17. Berlicki, Ł.; Rudzińska, E.; Kafarski, P. Tetrahedron: Asymmetry 2003, 14, 1535.

18. Zymanczyk-Duda, E.; Skwarczynski, M.; Lejczak, B.; Kafarski, P. Tetrahedron: Asymmetry 1996, 7, 1277.

19. Doskocz, M.; Malinowska, B., Młynarz, P., Lejczak, B., Kafarski P. Tetrahedron Lett. 2010, $51,3406$.

20. Texier-Boullet, F.; Lequitte, M. Tetrahedron Lett. 1986, 27, 3515.

21. Kozłowski, J.; Rath, P. N.; Spilling D. Ch. Tetrahedron 1995, 51, 6385.

22. Dale, J. A.; Mosher, H. S. J. Am. Chem. Soc. 1973, 95, 512. 